\title{
PERILAKU PENCARIAN INFORMASI MAHASISWA STAINU JAKARTA
}

\section{Siti Rozinah \\ Prodi Pendidikan Agama Islam}

\section{PENDAHULUAN}

Perkembangan informasi sangat bermanfaat dalam memenuhi kebutuhan informasi. Tingkat kebutuhan setiap orang berbeda-beda, semakin tinggi tingkat kebutuhan akan informasi maka perilaku pengguna untuk mencari dan menemukan informasi juga semakin aktif. Tentunya informasi yang dibutuhkan adalah informasi yang relevan dan akurat dan dapat membantu mengatasi masalah yang sedang dihadapi. Tingkat kebutuhan tersebut mengakibatkan adanya perbedaan perilaku setiap pengguna informasi dalam melakukan pencarian informasi. Pencarian informasi adalah suatu kegiatan yang dilakukan seseorang untuk mendapatkan informasi.

Perilaku dalam pencarian informasi diistilahkan sebagai information searching behaviour. Menurut Wilson (2000) "perilaku pencarian informasi adalah upaya pencarian informasi yang digunakan oleh pencari informasi ketika berinteraksi dengan sistem informasi”. Dalam hal ini pengguna informasi menyadari adanya kebutuhan yang harus dipenuhi untuk kelangsungan kegiatan sehari-hari pengguna informasi.

Perpustakaan Perguruan Tinggi yang merupakan jantung dari sebuah institusi pendidikan menyediakan berbagai informasi yang dibutuhkan seluruh sivitas akademika dalam proses pendidikan. Library is the heart of educational process. Idealnya, perguruan tinggi yang baik haruslah memiliki perpustakaan yang baik. Begitu pula sebaliknya, perpustakaan yang tidak baik perlu dicurigai memiliki perpustakaan yang tidak baik. Sebagai sebuah jantung pendidikan, perpustakaan perguruan tinggi menggerakan dan mengaliri semua proses belajar mengajar di perguruan tinggi. Perpustakaan seperti ini bukan hanya sekedar menunjang proses pendidikan, tetapi juga menjadi sumber informasi (the source of information).

Perpustakaan perguruan tinggi adalah perpustakaan yang terdapat pada perguruan tinggi atau badan bawahannya, maupun lembaga yang berafiliasi dengan perguruan tinggi, dengan tujuan utama memberikan jalan demi tercapainya tujuan perguruan tinggi. Perpustakaan perguruan tinggi adalah unit kerja yang merupakan bagian yang integral dari suatu lembaga perguruan tinggi induknya, yang bersama- 
sama dengan unit kerja bagian lainnya tetapi dalam peranan yang berbeda melaksanakan program Tri Dharma. (Direktorat Jenderal Pendidikan Tinggi, 1991: 1).

Sekolah Tinggi Agama Islam Nahdlatul Ulama Jakarta -yang seterusnya dalam penulisan ini disebut STAINU Jakarta-merupakan sekolah tinggi yang didirikan oleh sebuah yayasan yang bernaung pada organisasi masyarakat yaitu Nahdlatul Ulama (NU). STAINU Jakarta merupakan sekolah tinggi memiliki perpustakaan yang bisa dikatakan belum memenuhi Standar perpustakaan perguruan tinggi. Dalam Standar Nasional Indonesia (SNI) Perpustakaan Perguruan Tinggi nomor 7330.2009 berdasarkan Surat Keputusan Kepala Badan Standarisasi Nasional Nomor 82/KEP/BSN/9/2009 tentang Penetapan 4 (empat) Standar Nasional Indonesia menyebutkan bahwa "Perpustakaan menyediakan gedung dengan ruang yang cukup untuk koleksi, staf dan penggunanya. perpustakaan harus menyediakan ruang sekurang-kurangnya $0,5 \mathrm{~m}^{2}$ untuk setiap mahasiswa" Ruang penyimpanan koleksi yang dimiliki oleh STAINU Jakarta berada satu ruang dengan administrasi sekolah, karena jumlah koleksi yang dimiliki pun hanya 453 eksemplar dengan jumlah 313 judul.

Berdasarkan data di atas penulis ingin meneliti bagaimana mahasiswa di STAINU Jakarta mendapatkan informasi untuk memenuhi kebutuhan dalam penulisan skripsi. Bagaimana pula perilaku mahasiswa STAINU Jakarta dalam mencari informasi yang dibutuhkan, serta kendala-kendala yang dihadapi dalammemperoleh informasi.

\section{PERUMUSAN MASALAH}

Dari rumusan masalah di atas maka pertanyaan dalam penelitian ini adalah:

1. Apa saja kebutuhan informasi mahasiswa STAINU Jakarta? Berkaitan dengan penulisan skripsi meliputi sumber informasi, jenis sumber informasi yang digunakan, dan lokasi perolehan sumber informasi;

2. Bagaimanakah perilaku pencarian informasi mahasiswa STAINU Jakarta? Masalah yang akan diteliti adalah kegiatan yang dilakukan oleh mahasiswa dalam pencarian informasi; dan

3. Apa saja kendala yang dihadapi oleh mahasiswa ketika melakukan pencarian informasi?

\section{TINJAUAN PUSTAKA}

Informasi adalah data yang diolah dan dibentuk menjadi lebih berguna dan lebih berarti bagi yang menerimanya. Informasi merupakan pengumpulan dan pengolahan data untuk memberikan keterangan atau pengetahuan. Maka dengan 
demikian sumber informasi adalah data. Data adalah kesatuan yang menggambarkan suatu kejadian atau kesatuan nyata. Davis (2009:71) mendefinisikan informasi sebagai hasil dari olahan sebuah data yang memberikan pemahaman, wawasan, kesimpulan, keputusan, konfirmasi atau rekomendasi bagi si penerima. Informasi tersebut dapat berupa laporan, analisis, data yang terorganisir dalam output yang dapat dimengerti, respon verbal, grafik, gambar atau video.

Informasi merupakan hal yang sangat penting dalam pengambilan keputusan atau kesimpulan. Suatu keputusan atau kesimpulan yang tidak didukung informasi yang cukup biasanya kurang akurat atau tidak dapat memberikan hasil yang memuaskan.

Informasi juga merupakan suatu rekaman fenomena yang diamati, atau bisajuga berupa putusan-putusan yang dibuat seseorang. Suatu kejadian atau suatu gejala alam yang diamati seseorang kemudian dapat direkam baik dalam pikiran orang yang mengamati atau juga dapat terekam di dalam sebuah alat yang dapat menyimpan sebuah fenomena adalah informasi. Kemudian dijelaskan juga bahwa sebuah keputusan yang dibuat seseorang dari hasil pengamatan juga merupakan informasi.

Fungsi informasi bisa berkembang sesuai dengan bidang garapan yang disentuhnya. Namun, setidaknya yang utama adalah sebagai data dan fakta yang membuktikan adanya suatu kebenaran, sebagai penjelas hal-hal yang sebelumnya meragukan, sebagai prediksi untuk peristiwa-peristiwa yang mungkin akan terjadi pada masa yang akan datang. Nyatanya, informasi itu banyak fungsinya. Tidak terbatas pada salah satu bidang atau aspek saja, melainkan menyeluruh, hanya bobot dan manfaatnya yang berbeda karena disesuaikan dengan kondisi yang membutuhkannya (Saepudin, 2009).

\section{CIRI-CIRI DAN JENIS INFORMASI}

Menurut Davis (2009:72) informasi mempunyai ciri-ciri sebagai berikut:

1. Benar/salah: berhubungan dengan kebenaran terhadap kenyataan;

2. Baru: informasi yang dihasilkan benar-benar baru bagi penerimanya;

3. Tambahan informasi yang dapat diperbaharui: memberikan adanya perubahan terhadap informasi yang telah ada;

4. Korektif: digunakan untuk melakukan koreksi terhadap informasi sebelumnya yang salah; dan

5. Penegasan: dapat dipertegas informasi yang telah ada sehingga keyakinan terhadap informasi semakin meningkat.

Sedangkan untuk jenis informasi Davis juga membaginya ke dalam 
empat jenis yaitu:

1. Monitoring information: yaitu jenis informasi yang berfungsi untuk mengkonfirmasi tindakan yang diambil;

2. Problem finding information: informasi harus mewakiliatau menjawab masalah yang ada;

3. Action information: informasi yang menggambarkan bahwa akan diambil sebuah tindakan; dan

4. Decision support: hasil dari tindakan yang telah diambil, akan dijadikan bahan untuk mengambil keputusan.

Informasi sesuai dengan ciri-cirinya berarti memiliki sifat membenarkan yang berhubungan dengan kenyataan. Bila informasi salah tetapi penerima mempercayainya maka informasi itu bisa dikatakan benar. Informasi juga memiliki ciri pembaharuan yakni sesuatu yang baru bagi penerima informasi memperbaharui sat atau memberikan tambahan informasi yang telah ada. Informasi juga dapat dijadikan bahan untuk mengambil suatu keputusan informasi yang didapat kemudian bisa digunakan oleh pengguna untuk memformulasikan sesuai dengan kebutuhannya.

Berbagai keputusan yang diambil manusia dalam menentukan langkah kehidupannya bersandar pada informasi yang dimilikinya baik tentang dirinya, lingkungannya maupun tentang orang lain yang berhubungan dengannya. Informasi itu sangat beragam baik dalam jenis tingkatan, maupun bentuknya. Dengan demikian, maka fungsng pada manfaatnya bagntuinya pun beragam pula karena akan bergantung pada manfaatnya bagi setiap orang yang kebutuhannya berbeda-beda

\section{SUMBER INFORMASI}

Sumber informasi dapat diperoleh dalam dokumen dan non- dokumen. Sumber informasi yang berupa dokumen dapat berbentuk buku, jurnal, majalah, hasil-hasil penelitian. Sedangkan sumber informasi non-dokumen adalah manusia, yakni teman, pustakawan, pakar, atau spesialis informasi. Seperti yang dinyatakan oleh Menurut Setiarso (1997:5-6) bahwa sumber informasi juga terdapat pada:

1. Manusia: Manusia sebagai sumber informasi dapat kita hubungi baik secara lisan maupun tertulis. Yang lazim digunakan untuk kontak langsung dengan sumber ini ialah pertemuan dalam bentuk ceramah, panel diskusi, konferensi, lokakarya, seminar dan lain-lain

2. Organisasi: Badan atau lembaga penelitian baik milik pemerintah maupun swasta yang bergerak dalam bidang sejenis merupakan sumber informasi 
penting termasuk industry dan himpunan profesi. Mereka memiliki kemampuan karena mempunyai fasilitas berupa tenaga peneliti, peralatan atau laboratorium, perpustakaan, dan jasa informasi yang tersedia.

3. Literatur: Literatur atau publikasi dalam bentuk terbaca maupun mikro merupakan sumber informasi yang cukup majemuk. Literatur dapat dikelompokkan menjadi:

a. literatur primer: bentuk dokumen yang memuat karangan yang lengkap dan asli. Jenisnya berupa makalah, koleksi karya ilmiah, buku pedoman, buku teks, publikasi resmi, berkala, dan lain-lain.

b. Literatur sekunder: disebut juga sebagai sarana dalam penemuan informasi pada literatur primer. Jenisnya berupa indeks, bibliografi, abstrak, tinjauan literatur, katalog induk, dan lain-lain

Sumber informasi merupakan sarana penyimpanan informasi. Sumber informasi yang beraneka ragam bentuk atau wadahnya, perlu diatur dan ditata dengan baik agar mudah dan cepat ditemukan sewaktu-waktu dibutuhkan. Informasi yang kita temukan sehari-hari bersumber dari mana saja dan sumber informasi tersebut adakalanya tidak memiliki tingkat relevansi yang tinggi.

\section{PERILAKU PENCARIAN INFORMASI}

Wilson (2000:49) mengartikan perilaku (behavior) sebagai: 1) Tingkah laku yang ditimbulkan dari diri seseorang; 2) Segala sesuatu yang dilakukan oleh benda hidup yang meliputi tindakan dan respons terhadap stimulant; dan 3) Respon seseorang, sekelompok orang atau spesies dari lingkungannya.

Perilaku pencarian informasi adalah upaya yang dilakukan oleh seseorang untuk memenuhi kebutuhannya. Perilaku pencarianinformasi merupakan tindakan yang dilakukan oleh pengguna dalam memenuhi kebutuhan informasi. Tindakan setiap orang pasti berbeda. Beberapa faktor akan mempengaruhi cara pengguna mencari informasi. Baik dari segi tingkat kebutuhan yang berbeda maupun dari kemampuan pengguna. Perilaku pencarian informasi berhubungan erat dengan kebutuhan informasi. ada beberapa informasi yang ditemukan tanpa melakukan pencarian, tetapi ketika seseorang membutuhkan informasi dengan sendirinya akan tercipta sebuah perilaku untuk mencari informasi yang dibutuhkan. Wilson juga menjelaskan bahwa perilaku pencarian informasi adalah Perilaku pencarian informasi (information searching behavior) merupakan perilaku di tingkat mikro, berupa 
perilaku mencari yang ditunjukkan seseorang ketika berinteraksi dengan sistem informasi. Perilaku ini terdiri dari berbagai bentuk interaksi dengan sistem, baik di tingkat interaksi dengan komputer (misalnya penggunaan mouse atau tindakan meng-klik sebuah link), maupun di tingkat intelektual dan mental (misalnya penggunaan strategi Boolean atau keputusan memilih buku yang paling relevan di antara sederetan buku di rak perpustakaan).

\section{MODEL PERILAKU PENCARIAN INFORMASI}

Ada beberapa model perilaku pencarian informasi, diantaranya adalah model yang diperkenalkan oleh Wilson berdasarkan pada dua propisisi, yaitu:

1. Bahwa kebutuhan informasi bukan kebutuhan utama atau primer, namun merupakan kebutuhan sekunder yang timbul karena keinginan untuk memenuhi kebutuhan dasarnya; dan

2. Bahwa dalam usahanya menemukan informasi menghadapi kendala (barries) sebagai variabel perantara (intervening variable), kendalatersebutkemungkinanakanmempengaruhi perilakunya.

Model diatas merupakan revisi dari model sebelumnya (1981) yang dikemukakan oleh Wilson. Kerangka dari kedua model tersebut tetap memiliki fokus yang sama yaitu kebutuhan informasi, faktor- faktor penghalang, dan mengenali perilaku penemuan informasi. Perbedaan model diatas dengan model sebelumnya adalah di dalam hal-hal berikut (Saepudin, 2009):

1. Penggunaan istilah intervening variable untuk menjelaskan kendala-kendala yang dihadapi dalam proses pecarian informasi;

2. Menunjukkan lebih banyak tipe perilaku penemuan informasi daripada sebelumnya (pencari aktif tetap menjadi fokus perhatian);

3. Pengolahan dan pemanfaatan informasi; dan

4. Didukung oleh tiga teori yaitu:

a. Teori tentang stres dan cara mengatasi masalah (stress and coping theory),

b. Teori tentang resiko dan imbalan,

c. Teori belajar sosial

Dalam literatur selanjutnya, Wilson menyebut barriers sebagai intervening variables (variabel penghalang). Kendala tersebut adalah:

1. kendala dari dalam individu (diri sendiri) yang meliputi ketidakmampuan memanfaatkan fasilitas, faktor biaya, penguasaan bahasa asing and waktu;

2. kendala dari antar individu (orang lain) yaitu ketika sumber 
informasi yang dibutuhkan oleh mahasiswa dimiliki oleh orang lain namun mengalami kendala dalam mengakses sumber informasi tersebut; dan

3. kendala dari lingkungannya yang meliputi fasilitas dalam mengakses informasi, keterbatasan koleksi, waktu perolehan informasi serta politik dan ideology. Dalam melakukan tugas- tugas pencarian informasinya kendala tersebut kemungkinan akan mempengaruhi perilakunya.

Wilson dalam Modelnya ingin menunjukkan bahwa keinginan seseorang untuk memenuhi kebutuhan dasarnya mendorongnya melakukan pencarian informasi. Hal yang harus pula diperhatikan adalah bahwa kebutuhan-kebutuhan tersebut timbul karena peran seseorang pada kehidupan sosialnya . Dalam kaitannya dengan penelitian ini peran yang diambil adalah peran mahasiswa STAINU Jakarta dalam pekerjaannya (work-role) yang diberi tugas menyusun skripsi pada di akhir masa perkuliahannya. Lingkungan tempat seseorang melakukan work-role, yakni lingkungan kerja, sosial budaya, ekonomi politik, dan lingkungan fisik akan berpengaruh terhadap perilaku pencarian informasi. Keterkaitan antara kebutuhan, kendala dan perilaku pencarian informasi dapat diuraikan dalam bentuk gambar di bawah ini:

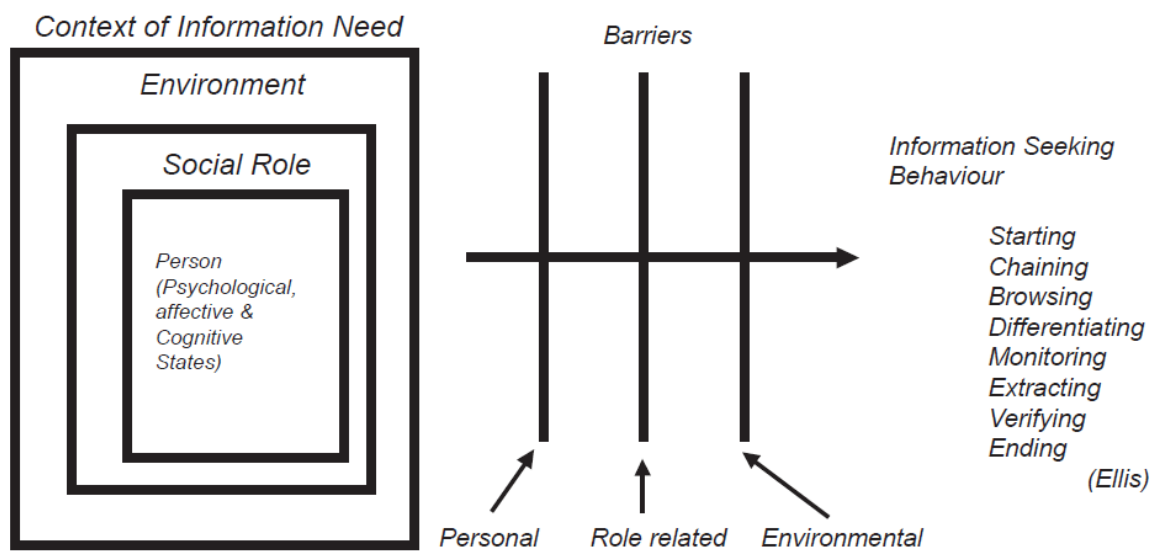

Gambar 1. Perilaku pencarian informasi model Wilson (1981) Sumber dari Natalya Godbold. (2006). Beyond information seeking: towards a general model of information behavior Information Research, Vol. 11 No. 4, July 2006

Selanjutnya pendekatan berdasarkan "proses kognitif' seseorang yang sedang mencari informasi menjadi telaah sendiri. Pendekatan yang digunakan adalah information search process (ISP) yang dilihat dari perspektif si pencari informasi. Berdasarkan pendekatan tersebut Kuhlthau (1991: 361-371) berhasil mengisolasi 6 tahapan dalam pencarian informasi sebagai berikut: inisiasi, seleksi, eksplorasi, formulasi, koleksi dan presentasi. 


\section{Tahap Inisiasi}

Tahap ini muncul ketika seseorang pertama kali menyadari adanya kebutuhan terhadap informasi tertentu. Tahap inisiasi ditandai oleh perasaan tidak yakin dan tidak pasti, yang mengakibatkan dilakukannya upaya-upaya mengaitkan situasi yang dihadapi dengan simpanan pengalaman yang dimilikinya dari masa lampau yang berhubungan dengan pencarian informasi.

\section{Tahap Seleksi}

Pada tahap ini pencari informasi mulai merasa optimis, karena informasi yang dikumpulkan dapat memenuhi kebutuhannya. Pola pikir mereka mulai diarahkan pada upaya mempertimbangkan informasi yang telah ditemukan dengan berbagai criteria seperti kepentingan pribadi, persyaratan dalam tugas-tugas yang harus diselesaikan, sumber informasi yang tersedia, dan waktu yang tersedia. pada tahap ini seseorang mulai berdiskusi dengan teman-temannya, dan mulai melakukan pemilihan informasi secara lebih sistematis.

\section{Tahap Eksplorasi}

Tahap mengatasi masalah keragu-raguan atau kebingungan yang disebabkan oleh perbenturan antar konsep yang ada dalam struktur kognisinya dengan kenyataan informasi yang didapat. Kebingungan ini terjadi biasanya setelah seseorang tersebut menyelesaikan tahap seleksi yang sudah dijelaskan di atas. Untuk mengatasi masalah tersebut pola pikir mereka mulai diarahkan pada upaya-upaya menemukan titik orientasi yang dapat membantu untuk menemukan sisi pandang yang sesuai dengan kepentingannya.

\section{Tahap Formulasi}

Tahap ini merupakan tahap penentuan, karena perasaan tidak pasti mulai terkikis dan rasa percaya diri mulai tumbuh. Pola pikir mereka sudah terfokus untuk memilih ideide dari informasi yang dikumpulkan untuk membentuk perspektif tentang topik yang sedang ditekuninya. Bila tahap ini sudah terlampaui, maka akan berlanjut pada Tahap Interaksi.

\section{Tahap Interaksi}

Menurut Kuhlthau pada tahap ini terjadi suatu "interaksi antara pemakai dengan sistem informasi yang paling intensif dan efisien", dalam tahap ini pola pikir mereka dikonsentrasikan pada upaya memperjelas, memperluas, dan mengumpulkan informasi 
tentang topik yang digelutinya. Mereka mulai mencatat segala informasi yang dianggap relevan dengan bidangnya.

\section{Tahap Presentasi}

Ini merupakan tahap puncak dari pencarian informasi yang akan berakhir dengan dua kemungkinan merasa puas atau sebaliknya. Apapun yang terjadi, seseorang dalam tahap ini telah berani dan merasa siap untuk menyajikan pendapatnya sendiri dalam bentuk karya tulis. Pola pikir yang dihasilkan merupakan sintesa dari berbagai sumber informasi dan juga mulai melibatkan egonya berupa pendapat pribadi berdasarkan pijakan informasi sebelumnya.

Berdasarkan tahap-tahap tersebut dapat dinyatakan bahwa pola pencarian informasi sifatnya berjenjang, dimulai dari suatu yang serba tidak jelas, serba tidak pasti sampai pada tahap adanay titik kejelasan dari informasi yang dicarinya.

Secara lebih terperinci proses pencarian yang dilihat dari sudut pandang kognisi pencari informasi dapat dilihat dalam table berikut ini:

\section{Table No. I INFORMATION SEARCH PROCESS}

(Proses Pencarian Informasi)

\begin{tabular}{|c|c|c|c|}
\hline $\begin{array}{l}\text { Tahap-tahap } \\
\text { dalam ISP }\end{array}$ & $\begin{array}{l}\text { Perasaan yang } \\
\text { muncul dalam } \\
\text { suatu tahap }\end{array}$ & $\begin{array}{c}\text { Pola pikir yang } \\
\text { muncul pada } \\
\text { setiap } \\
\text { tahap }\end{array}$ & $\begin{array}{l}\text { Tindakan yang } \\
\text { biasanya dilaku- kan } \\
\text { setiap tahap }\end{array}$ \\
\hline 1. Inisiasi & $\begin{array}{l}\text { Ketidakpas- } \\
\text { tian }\end{array}$ & $\begin{array}{l}\text { Umum/ Sa- } \\
\text { mar-samar }\end{array}$ & $\begin{array}{l}\text { Mencari Informa- } \\
\text { si latar belakang }\end{array}$ \\
\hline 2. Seleksi & Optimisme & $\begin{array}{l}\text { Penuh pertim- } \\
\text { bangan }\end{array}$ & $\begin{array}{l}\text { Berdiskusi, mem- } \\
\text { ulai seleksi }\end{array}$ \\
\hline 3. Eksplorasi & $\begin{array}{l}\text { Kebingungan/ } \\
\text { Frustasi }\end{array}$ & - & $\begin{array}{l}\text { Mencari informa- } \\
\text { si yang relevan }\end{array}$ \\
\hline 4. Formulasi & Kejelasan & $\begin{array}{l}\text { Lebih sempit/ } \\
\text { lebih jelas }\end{array}$ & - \\
\hline $\begin{array}{l}\text { 5. Koleksi } \\
\text { Pengum- } \\
\text { pulan }\end{array}$ & Keyakinan & $\begin{array}{l}\text { Peningkatan } \\
\text { rasa tertarik }\end{array}$ & $\begin{array}{l}\text { Mencari informa- } \\
\text { si secara lebih ter- } \\
\text { fokus }\end{array}$ \\
\hline 6. Presentasi & $\begin{array}{l}\text { Lega, puas } \\
\text { atau juga ke- } \\
\text { cewa }\end{array}$ & $\begin{array}{l}\text { Lebih jelas, } \\
\text { lebih terfokus }\end{array}$ & - \\
\hline
\end{tabular}


Sumber: Kuhlthau, "Inside the Search process: Information seeking from the user's prospective" dalam Jurnal of The American Society for Information Science (JASIS) 42 (4) 1991 halaman 367.

Model selanjutnya adalah behavioral model of information seeking strategies yang diperkenalkan David Ellis pada tahun 1987 dari hasil analisis pola-pola pencarian informasi dikalangan peneliti bidang ilmu-ilmu sosial. Hasil penelitian ini merupakan pola pencarian informasi yang terdiri dari enam tahap yaitu: starting, chaining, browsing, differentiating, monitoring, dan extracting. Kemudian pada tahun 1993 model ini dikembangkan Ellis bersama dengan Cox dan Hall dengan membandingkan pola pencarian informasi peneliti bidang ilmu sosial dengan peneliti bidang fisika dan kimia sehingga menghasilkan depalan tahapan pencarian informasi yang terdiri dari starting, chaining, browsing, differentiating, monitoring, extracting, verifiying dan ending.

Berikut ini kedelapan tahapan pencarian informasi (Ellis, Cox dan Hall, 1993:359-365):

1. Starting

Starting merupakan titik awal pencarian informasi atau pengenalan awal terhadap rujukan. Seringkali informasi ditemukan pada saat starting merupakan topik penelitian yang dapat dikembangkan untuk melakukan penelitian lebih lanjut. Pada saat starting digunakan penelusuran sebagai berikut:

a. Rujukan awal (starter references)

Rujukan awal merupakan titik awal untuk mendapatkan bahan rujukan selanjutnya. Biasanya didapatkan dari atasan, teman sejawat atau dari kumpulan catatan yang dibuat sendiri mengenai rujukan yang berhubungan dengan topik yang diminati.

b. Tinjauan atau synopsis artikel (preview or synoptic articles) Preview atau ulasan artikel digunakan tidak hanya sebagai sumber rujukan menuju bahan primer tetapi juga sebagai kerangka untuk dapat memahami isi dari bahan rujukan

c. Sumber Sekunder (secondary resources)

Sumber sekunder seperti abstrak, indeks dan catalog subjek digunakan untuk 
mencari informasi dalam rangka memilih topik penelitian yang diminati oleh peneliti.

2. Chaining

Chaining diidentifikasikan sebagai hal yang penting pada pola pencarian informasi. Kegiatan ini ditandai dengan mengikuti mata rantai atau mengaitkan daftar literature yang pada rujukan inti. Chaining dapat dilakukan dengan dua cara yaitu:

a. Backward chaining

Merupakan cara tradisional yakni mengikuti daftar pustaka yang ada pada rujukan inti, sehingga rujukan selanjutnya merupakan rujukan-rujukan yang pernah disitir pada rujukan inti. Dengan melakukan cara mengaitkan ke belakang, akan dihasilkan efek bola salju, sehingga hanya dengan menggunakan satu rujukan inti saja akan didapatkan beberapa rujukan lain yang tidak akan berbeda jauh dengan masalah yang dibahas pada rujukan inti.

b. Forward chaining

Mencari rujukan lain berdasarkan subjek atau nama pengarang dari rujukan inti yang telah ada dengan mengaitkan ke depan. Cara ini dilakukan dengan menggunakan sarana bibliografi.

Ciri-ciri chaining adalah: a) Mencari bahan rujukan berdasarkan daftar literature yang tertera pada rujukan inti. b) mencari bahan rujukan di luar dafrtar rujukan inti, akan tetapi tetap berpedoman pada subjek atau pengarang yang ada pada rujukan inti.

\section{Browsing}

Merupakan tahap kegiatan yang ditandai dengan kegiatan pencarian informasi dengan cara penelusuran semi terstruktur karena telah mengarah pada bidang yang diamati. Kegiatan pada tahap ini efektif untuk mengetahui tempat-tempat yang menjadi sasaran potensial untuk ditelusuri. Browsing dapat dilakukan dengan berbagai cara antara lain melalui abstrak hasil penelitian, daftar isi jurnal, jajaran buku di perpustakaan atau toko buku, bahkan juga buku-buku yang dipajang pada pameran atau seminar.

4. Differentiating

Merupakan kegiatan membedakan sumber informasi untuk menyaring informasi berdasarkan sifat kualitas rujukan. Kriteria untuk memilih rujukan yang akan 
digunakan adalah:
a. Topik kajian
b. Pendekatan yang digunakan
c. Kualitas atau jenis perlakuan

Identifikasi sumber-sumber informasi terutama ditekankanpada subjek-subjek yang dipilih dan selanjutnya akan mengambil bahan- bahan dan topik yang diminati.

\section{Monitoring}

Merupakan kegiatan yang ditandai dengan kegiatan memantau perkembangan yang terjadi terutama dalam bidang yang diminati dengan cara mengikuti sumber secara teratur. Monitoring dapat dilakukan dengan cara yaitu:

a. Melalui hubungan formal (informal contact) Digunakan sebagai pra seleksi sumber dan bahan yang

akan digunakan. Cara ini merupakan ajang untuk bertukar informasi, baik dengan sejawat maupun pakar bidang tertentu.

b. Membaca jurnal (monitoring journal)

Biasanya monitoring dilakukan terhadap sumber inti dalam jumlah kecil tetapi telah terseleksi dan diikuti secara seksama. Misalnya beberapa judul majalah yang dipilih sesuai dengan bidang yang diminati, diikuti perkembangannya setiap terbit, minimal dari judul-judulnya saja seperti pada current content.

c. Monitoring katalog (monitoring material published in bookform) Kegiatan ini dapat dilakukan dengan melihat daftar terbitan secara berkala, preview atau bibliografi berkelanjutan dan melakukan akses secara berkala ke perpustakaan.

\section{Extracting}

Kegiatan yang dilakukan pada tahap ini terutama diperlukan pada saat harus membuat tinjauan literatur. Sumber informasi yang digunakan pada extracting ini adalah jurnal terutama jurnal- jurnal yang sudah standar, katalog penerbit, bibliografi subjek, abstrak dan indeks.

\section{Verifying}

Ditandai dengan kegiatan pengecekan atau penilaian apakah informasi yang didapat telah sesuai atau tepat dengan yang diinginkan. Sebagai perbandingan peneliti bidang ilmu sosial tidak melakukan tahapan ini, berbeda dengan peneliti bidang fisika 
dan kimia yang melalui tahapan ini dengan melakukan pengujian untuk memastikan seandainya ada kesalahan-kesalahan pada informasi yang diperoleh.

8. Ending

Tahap ending juga merupakan kategori perilaku yang tidak dijumpai pada kajian Ellis (1987). Merupakan tahap akhir dari pola pencarian informasi biasanya dilakukan bersamaan dengan berakhirnya suatu kegiatan penelitian.

\section{KENDALA DALAM PENCARIAN INFORMASI}

Pada saat penulisan skripsi, dapat dipastikan bahwa mahasiswa akan mengalami suatu kendala dalam pencarian informasi. Kendala tersebut disebabkan oleh faktor internal pencari informasi sendiri - dalam hal ini adalah mahasiswa- atau disebabkan oleh faktor internal dan eksternal. Tentu saja kendala-kendala tersebut akan berbeda bagi setiap mahasiswa. Segala tindakan manusia didasarkan pada suatu keadaan dipengaruhi oleh lingkungan, pengetahuan, situasi dan tujuan yang ada pada diri manusia (Wersig \& Windel, 1985).

\section{PERILAKU PENCARIAN INFORMASI MAHASISWA}

Model yang menggambarkan pola kebutuhan dan perilaku penemuan informasi juga dihasilkan melalui sebuah penelitian yang dilakukan oleh Qureshi, Zafar, dan Khan (2002) terhadapmahasiswa dari beberapa univeristas di Pakistan. Penelitian ini menggunakan beberapa karakteristik perilaku mahasiswa yang diperkirakan akan berpengaruh terhadap perilaku membutuhkan informasi dan perilaku penemuan informasi. Karakteristik-karakteristik perilaku mahasiswa tersebut adalah: pemahaman mahasiwa terhadap informasi, kondisi lingkungan mahasiswa, partisipasi mahasiswa, kemampuan mahasiswa dalam menggunakan media informasi, latar belakang budaya dan pendidikan mahasiswa, evaluasi diri mahasiswa, dan minat mahasiswa.

\section{HASIL PENELITIAN}

Pada penelitian ini, penulis mewawancarai 10 (sepuluh) orang informan yang seluruhnya adalah mahasiswa jurusan Pendidikan Agama Islam (PAI) Sekolah Tinggi Agama Islam Nahdlatul Ulama (STAINU) Jakarta yang menulis skripsi. 
Dari hasil penelitian mengenai perilaku pencarian informasi mahasiswa dalam memenuhi kebutuhan penulisan skripsi di STAINU Jakarta yang telah dilakukan ini dapat diketahui kesimpulannya sebagai berikut:

\section{Kebutuhan informasi}

Kebutuhan informasi mahasiswa penulis skripsi berdasarkan sumber informasi yang digunakan untuk memenuhi kebutuhan penulisan skripsi yaitu: buku teks yang menjadi acuan utama, jurnal sebagai bahan tambahan, individu baik dari pejabat sekolah, tokoh agama, nelayan dan siswa dijadikan sebagai informan/responden, dan artikel-artikel yang di unduh dari internet.

Kebutuhan informasi berdasarkan lokasi perolehan informasi yang paling pertama dikunjungi adalah Perpustakaan Nasional yang letaknya berdekatan dengan kampus STAINU Jakarta. Sedangkan perpustakaan PBNU digunakan untuk mencari informasi-informasi yang berkaitan dengan pendidikan agama seperti fiqih dan akhlak.

\section{Perilaku pencarian informasi}

Model tahapan pencarian informasi yang ditemukan oleh Ellis yakni starting, chaining, browsing, differentiating, monitoring dan ekstracting merupakan perilaku pencarian informasi para mahasiswa penulis skripsi. Dari 6 (enam) tahapan ini ada 2 (dua) tahapan yang tidak dilakukan secara khusus oleh mahasiswa penulis skripsi yakni monitoring dan ekstracting. Dua tahapan ini secara tidak langsung dilakukan pada saat proses pencarian informasi dan penulisan skripsi. Oleh karena itu dapat dikatakan bahwa secara keseluruhan mahasiswa penulis skripsi melakukan tahapan kegiatan perilaku pencarian informasi dari Ellis ini.

\section{Hambatan-hambatan}

Hambatan yang dihadapi mahasiswa penulis skripsi yang paling siginifikan adalah yang berasal dari lingkungan yaitu ketersediaan koleksi yang sangat terbatas di perpustakaan STAINU Jakarta sehingga mahasiswa penulis skripsi harus mencari sumber informasi di lembaga informasi lain. Serta jaringan internet yang kurang memadai menambah keterbatasan mahasiswa dalam memenuhi kebutuhan informasinya.

\section{DAFTAR PUSTAKA}


Davis, Gordon B. (2009). Management information system: conceptual foundation, structure and developmenet. Second Edition. New York: McGraw Hills. June $27,2011$.

citeseerx.ist.psu.edu/viewdoc/download?doi=10.1.1.90.9811. Fisher, Karen E., Sanda Endelez \& Lynne (E.F.) McKechnie. (Ed.)

(2006). Theories of information behavior. New Jersey: Asist Monograph Series

Godbold, Natalya. (2006). Beyond information seeking: towards a general model of information behavior Information Research, Vol. 11 No. 4, July 2006. March 14, 2011 http://informationR.net/ir/11-4/paper269.html

Harisanty, Dessy. (2009) Kebutuhan informasi siswa SMA dan ketersediaan sumber informasi pada perpustakaan SMA di Surabaya. 27 Juni 2011. http://palimpsest.fisip.unair. ac.id/images/pdf/Dessy.pdf.

Joyce, Bruce \& Marsha Weil. (1985). Models of teaching. New Delhi: Prentice Hall of India private limited.

Kaniki, Andrew M. (1992). Meeting the needs of agricultural researchers in Afrika: the role of unpublish reports. Information Development. 8 (2): 83-90

Koentjaraningrat. (1990). Metode-metode penelitian masyarakat.

Jakarta: Gramedia Pustaka Utama.

Kuhlthau, Carol C. Inside the Search Process: Information Seeking From the User's Perspective. June 04, 2011

http://comminfo.rutgers.edu/ kuhlthau/docs/10.1.1.119.2997.pdf 